\title{
PEMBUATAN BRIKET BIOARANG DARI CANGKANG DAN TANDAN KOSONG KELAPA SAWIT
}

\section{BIOARANG BRIQUETTE MAKINGS FROM CANGKANG AND OILS PALM EMPTY BUNCH}

\author{
Anto Susanto ${ }^{1) \cdot}$ dan Tri Yanto ${ }^{2) .}$ \\ 1). Jurusan Teknologi Pertanian Politeknik Ketapang, \\ 2).Pascasarjana Pertanian Universitas Jenderal Soedirman \\ E-mail :antosusanto@ymail.com
}

\begin{abstract}
Energy and fuel crisis was become since 1970s, in 1980s in 1980s began to think about the possibility of depletion of fuel reserves of non-renewable resources and seek alternative fuel sources One way to reduce oil consumption and use the land is the utilization of palm oil processing wastes into biocharcoal briquettes, where the constituent ingredients derived from oil palm empty fruit bunches and oil palm shell. The purpose of this research was to obtain the optimum basic formulation to getting quality biocharcoal briquette having quality standards including: moisture content, ash content, levels of substance evaporates, bonded carbon content, density, firmness press, and the calorific fuel value. The research method that used was experiment Completely Randomized Block Design (CRBD) with Two factors : (1) oil palm shell compositions with oil palm empty fruit bunches 4 levels ; 1:10, 1:15, 1:20, 1:25, and (2) concentration of starch adhesives are used ; $0 \%, 2 \%, 4 \%$ and $6 \%$. The data was analyzed with variance analysis (ANOVA) and to determine the different treatments, was used the regression analysis and Duncan's Multiple Range Test (DMRT) at 5\% level. The results showed that the addition of ratio concentration starch adhesive composition of oil palm shell and oil palm empty fruit bunches is respectively, on the moisture content, ash content, levels of substance evaporates, bonded carbon content, density, firmness press and calorific valuefuel biocharcoal briquette. Treatment of 2\% starch with 1:20 oil palm empty fruit bunches with oil palm shell and provide products was showed the best: oil palm empty fruit bunches biocharcoal briquette with moisture content(6.97\%), ash content (19.54\%), vaporized substance (28.67 $\%)$, bound of carbon content (51.78\%), density $(1.14 \mathrm{~g} / \mathrm{cm} 3$ persistence press $(14.45 \mathrm{~kg} / \mathrm{m} 2)$, and fuel calorific (5069 cal/g).
\end{abstract}

Key word: biocharcoal briquette, oil palm empty fruit bunches, oil palm shell

\section{ABSTRAK}

Krisis energi dan bahan bakar sudah terjadi sejak akhir tahun 1970, sehingga awal tahun 1980 mulai dipikirkan tentang kemungkinan habisnya cadangan bahan bakar dari sumber yang tidak terbarukan dan mencari sumber bahan bakar alternatif. Salah satu cara untuk mengurangi konsumsi minyak tanah adalah pemanfaatan dan penggunaan limbah hasil pengolahan kelapa sawit (PKS) menjadi briket bioarang, dimana bahan-bahan penyusunnya berasal dari tandan kosong dan cangkang kelapa sawit. Tujuan penelitian secara umum untuk mendapatkan formulasi dasar yang optimum dalam mendapatkan mutu briket bioarang yang memiliki standar mutu diantaranya: kadar air, kadar abu, kadar zat menguap, kadar karbon terikat, kerapatan, keteguhan tekanan, dan nilai kalor. Adapun tujuan khusus penelitian: (1) mengetahui pengaruh perbandingan komposisi cangkang dan tankos kelapa sawit; (2) mengetahui pengaruh perlakuan penambahan konsentrasi perekat kanji; dan (3) mengetahui interaksi antara perlakuan perbandingan penambahan komposisi cangkang dan tankos kelapa sawit dengan perlakuan penambahan konsentrasi perekat kanji terhadap mutu briket bioarang.

Penelitian yang dilakukan merupakan eksperimental faktorial dengan rancangan percobaan Rancangan Acak Kelompok (RAK). Faktor yang dicoba dalam penelitian adalah: (1) perlakuan perbandingan komposisi cangkang dan tankos kelapa sawit (P), terdiri dari 4 taraf; perbandingan komposisi cangkang dan tankos 1:10 (P1), perbandingan komposisi cangkang dan tankos 1:15 (P2), perbandingan komposisi cangkang dan tankos 1:20 (P3), perbandingan komposisi cangkang dan tankos 1:25 (P4), dan (2) perlakuan konsentrasi perekat kanji yang digunakan (K), yang terdiri dari 4 taraf ; konsentrasi $0 \%$ kanji (K0), konsentrasi $2 \%$ kanji (K1), konsentrasi $4 \%$ kanji (K2), konsentrasi $6 \%$ kanji (K3). Hasil pengamatan di uji dengan Analisis of Variance (ANOVA) dan untuk mengetahui perlakuan yang berbeda, maka analisis dilanjutkan dengan analisis regresi dan uji Duncan's Multiple Range Test (DMRT) pada taraf $5 \%$.

Hasil penelitian menunjukan bahwa penambahan konsentrasi perekat kanji (K) dengan perbandingan komposisi bahan cangkang dan tandan kosong kelapa sawit $(\mathrm{P})$ maupun interaksi antara keduanya ( $\mathrm{K} \times \mathrm{P})$ memberikan pengaruh sangat nyata terhadap variabel pengamatan kadar air, kadar abu, kadar zat menguap, kadar karbon terikat, kerapatan, keteguhan tekan maupun nilai kalor bakar briket bioarang. Perlakuan K0P1 menghasilkan nilai kadar air paling kecil (5,7 \%); K1P1 menghasilkan nilai kadar abu paling kecil (13,1 \%); K0P4 menghasilkan nilai kadar zat menguap paling kecil (21,4\%); dan menghasilkan nilai kadar karbon terikat paling besar (59,7\%); K3P2 menghasilkan nilai kerapatan paling besar $\left(1,5 \mathrm{~g} / \mathrm{cm}^{3}\right)$; dan menghasilkan nilai 
keteguhan tekan paling besar $\left(24,3 \mathrm{~kg} / \mathrm{m}^{2}\right)$; K0P3 dan K1P3 menghasilkan nilai kalor bakar paling besar (5169 $\mathrm{kal} / \mathrm{g}$ dan $5069 \mathrm{kal} / \mathrm{g})$.

Kata Kunci : perekat kanji, cangkang dan tandan kosong kelapa sawit.

\section{PENDAHULUAN}

Energi merupakan sektor utama dalam perekonomian Indonesia dewasa ini

$$
\text { dan tentunya akan }
$$

mengambil peranan yang lebih besar diwaktu yang akan datang baik dalam rangka penyediaan devisa, penyerapan tenaga kerja, pelestarian sumberdaya energi, pembangunan nasional maupun pembangunan daerah. Dalam upaya mengatasi krisis energi terutama minyak tanah, pemerintah menerapkan kebijakan konversi minyak tanah ke gas. Namun, konversi ini memerlukan proses dan sosialisasi yang panjang, selain itu membutuhkan dana yang besar serta pengolahan yang profesional. Keterbatasan pengetahuan dan budaya masyarakat juga menjadi salah satu penyebab program tersebut kurang sesuai dilakukan di pedesaan. Menyiasati kelangkaan minyak tersebut masyarakat pedesaan lebih memilih menggunakan kayu bakar. Jika hal ini terus berlanjut dapat menimbulkan kerusakan lingkungan.

Salah satu cara untuk mengurangi konsumsi minyak tanah adalah pemanfaatan dan penggunaan limbah hasil pengolahan kelapa sawit (PKS) menjadi briket bioarang, dimana bahan-bahan penyusunnya berasal dari tandan kosong dan cangkang kelapa sawit. Bahan penyusun yang disebutkan adalah limbah yang berasal dari pabrik pengolahan kelapa sawit (Mulia, 2007). Briket bioarang merupakan salah satu sumberenergi alternatif yang dapat digunakan untukmenggantikan sebagian dari kegunaan minyak tanah. Briket bioarang merupakan bahan bakar yang berwujud padat dan berasal dari sisa-sisa bahan organik (Budiman et al., 2011).

Briket bioarang yang baik tersebut tentunya harus mengetahui terlebih dahulu formulasi bahan baku yang optimum dan konsentrasi penambahan perekat kanji yang digunakan. Perekat tapioka umum digunakan sebagai bahan perekat pada briket bioarang, karena banyak terdapat di pasaran dan harganya relatif murah. Perekat ini dalam penggunaannya menimbulkan asap yang relatif sedikit dibandingkan bahan lainnya. Agar diperoleh komposisi bahan baku dan perekat yang optimum pada pembuatan briket bioarang, maka perlu dilakukan penelitian lebih lanjut. Tujuan penelitian, diantaranya: mengetahui pengaruh komposisi cangkang dan tandan kosong kelapa sawit; pengaruh penambahan konsentrasi perekat tapioka; dan interaksi antara penambahan komposisi bahan cangkang dan tandan kosong kelapa sawit dengan konsentrasi perekat tapioka terhadap mutu briket bioarang.

\section{METODE PENELITIAN}

\section{Bahan dan Alat}

Bahan yang digunakan pada penelitian, meliputi: limbah cangkang dari PT. Gunajaya Karya Gemilang Ketapang, tankos dari Pabrik Kelapa Sawit (PKS) PTPN VIII Serang, perekat (tapioka), air, barium hidroksida $0.1 \mathrm{~N}$, indicator phenol pthalaine, HCL $0.1 \mathrm{~N}$, dan $\mathrm{Na}_{2} \mathrm{CO}_{3} 0.1 \mathrm{~N}$.

Alat yang digunakan pada penelitian, diantaranya: media cetak briket bioarang berbentuk silinder, muffle furnance, Oven, bom calorimeter, crucible porcelain, timbangan analitis, desikator, silica gel, peralatan analitik dan hardener meter dan dongkrak hidrolik.

\section{Rancangan Penelitian}

Penelitian eksperimental faktorial dengan rancangan percobaan Rancangan Acak Kelompok (RAK). Faktor yang dicoba dalam penelitian ini adalah: 1) komposisi cangkang dan tandan kosong (P) 4 taraf: a. cangkang dan tankos 1:10 (P1); b. cangkang dan tankos 1:15 (P2); c. cangkang dan tankos 1:20 (P3); dan d. cangkang dan tankos 1:25 (P4); dan 2) perlakuan konsentrasi perekat tapioka (K) 4 taraf: a. konsentrasi $0 \%(\mathrm{~K} 0)$; b. konsentrasi $2 \%$ (K1); c. konsentrasi $4 \%$ (K2); d. konsentrasi 
$6 \%$ (K3).Data hasil pengamatan, dianalisis dengan ANOVA model analisis, sebagai berikut :

Dimana :

$$
\mathbf{Y}_{\mathrm{ijk}}=\boldsymbol{\mu}+\mathbf{A}_{\mathrm{i}}+\mathbf{B}_{\mathrm{k}}+\mathbf{A} \mathbf{B}_{\mathrm{ik}}+\mathbf{C}_{\mathrm{ijk}}
$$

$$
\begin{aligned}
& \mathrm{Y}_{\mathrm{ijk} k}= \text { nilai pengamatan. } \\
& \mu \text { nilai tengah populasi. } \\
& \mathrm{A}_{\mathrm{i}}= \text { pengaruh perlakuan } \\
& \text { penambahan } \\
& \text { cangkang dan tankos pada } \\
& \text { taraf ke-i. } \\
& \mathrm{B}_{\mathrm{k}}= \text { pengaruh perlakuan } \\
& \text { konsentrasi perekat pada taraf } \\
& \text { ke-k. } \\
& \mathrm{AB}_{\mathrm{ik}}= \text { pengaruh interaksi konsentrasi } \\
& \text { penambahan konsentrasi } \\
& \text { cangkang dan tankos pada } \\
& \text { tarak ke-i dengan konsentrasi } \\
& \text { perekat pada taraf ke-k. } \\
& \text { penaruh galat percobaan } \\
& \text { penambahan konsentrasi } \\
& \text { cangkang dan tankos pada } \\
& \text { taraf ke-i, konsentrasi perekat } \\
& \text { pada taraf ke-k ulangan ke } \mathrm{j}, \\
& \mathrm{C}_{\mathrm{ijk}} \text { dimana }: \\
& \mathrm{i}=1,2,3,4,5 \ldots, \mathrm{a} ; \\
& \mathrm{j}=1,2, \ldots \mathrm{u} ; \\
& \mathrm{k}=1,2,3,4 \ldots \mathrm{b} .
\end{aligned}
$$

\section{Tahapan Penelitian}

Proses pembuatan briket bioarang dalam penelitian dilakukan dengan beberapa tahap (Gambar 1), diantaranya:a). Tahap persiapan bahan baku; b). Tahap pengarangan; dan c). Tahap pencetakan dan pengeringan.

\section{HASIL DAN PEMBAHASAN}

Hasil analisis ragam menunjukan perlakuan komposisi bahan cangkang dan tankos (P) dengan konsentrasi perekat $(\mathrm{K})$ dengan serta interaksinya $\left(\begin{array}{lll}P & X & K\end{array}\right)$ berpengaruh sangat nyata terhadap karakteristik mutu briket baik nilai kadar air, kadar abu, kadar zat menguap, kadar karbon terikat, kerapatan, keteguhan tekanan, maupun nilai kalor bakar. Matrik hasil analisis ragam disajikan pada Tabel 1.
Limbah Cangkang dan

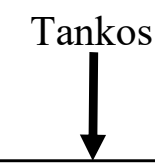

Karakteristik limbah cangkang

dan tandan kosong (Tankos)

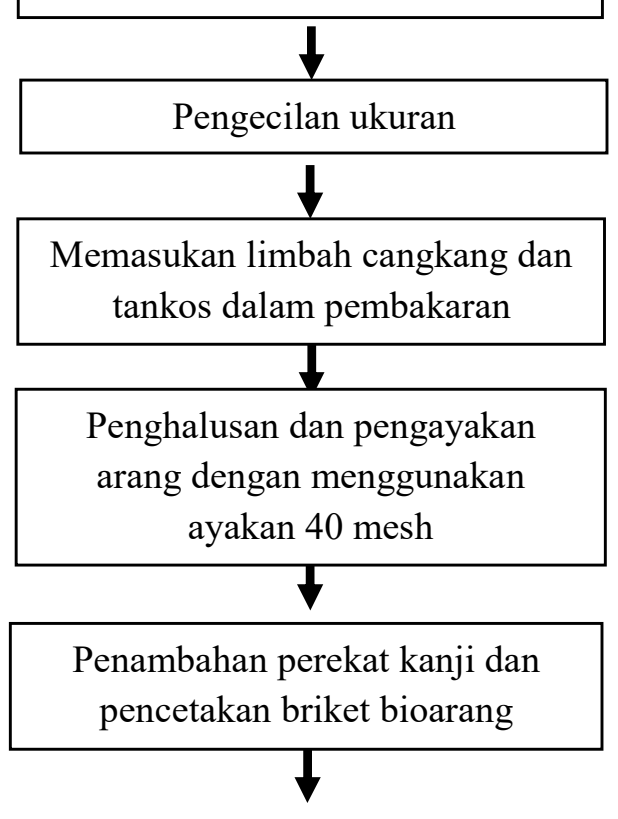

Briket bioarang yang sudah

dicetak dikeringkan

Pengujian, meliputi :

- kadar air (SNI 01-6235-2000)

- kadar abu (SNI 01-6235-2000)

- kadar zat mudah menguap (SNI 01-62352000)

- kadar karbon terikat (SNI 01-6235-2000)

- kerapatan (ASTM 1959)

- keteguhan tekan (ASTM 1959), dan

- nilai kalor (ASTM 1959)

Gambar 1. Proses Pembuatan Briket Bioarang

\section{A. Kadar Air}

Kadar air pada briket bioarang tankos diharapkan serendah mungkin agar dapat menghasilkan nilai kalor yang tinggi dan akan menghasilkan briket bioarang tankos yang mudah dalam penyalaan atau pembakaran awalnya.

Hasil uji lanjut DMRT pada taraf 5 persen menunjukan bahwa interaksi antara komposisi bahan dengan konsentrasi perekat 
Tabel 1. Matrik Hasil Analisis Ragam Perlakuan Komposisi Bahan Dengan Perekat

\begin{tabular}{clccc}
\hline \multirow{2}{*}{ No } & \multicolumn{2}{c}{ Variabel yang } & \multicolumn{3}{c}{ Perlakuan } \\
\cline { 3 - 5 } & \multicolumn{1}{c}{ diamati } & P & K & P x K \\
\hline 1 & Kadar air & $* *$ & $* *$ & $* *$ \\
2 & Kadar abu & $* *$ & $* *$ & $* *$ \\
3 & Kadar zat menguap & $* *$ & $* *$ & $* *$ \\
4 & Kadar karbon terikat & $* *$ & $* *$ & $* *$ \\
5 & Kerapatan & $* *$ & $* *$ & $* *$ \\
6 & Keteguhan tekan & $* *$ & $* *$ & $* *$ \\
7 & Nilai kalor bakar & $* *$ & $* *$ & $* *$ \\
\hline
\end{tabular}

Keterangan :

$\mathrm{P} \quad=$ perlakuan perbandingan komposisi bahan cangkang dan tankos kelapa sawit

$\mathrm{K}=$ perlakuan konsentrasi perekat tapioka;

$\mathrm{Kx} \mathrm{P}=$ interaksi antara perlakuan komposisi

bahancangkang dan tankos kelapa sawit

dengan konsentrasi perekat tapioka

** = berpengaruh sangat nyata

memberikan pengaruh sangat nyata terhadap nilai kadar air. Hubungan interaksi antara perbandingan komposisi bahan dengan konsentrasi perekat terhadap nilai kadar air briket bioarang disajikan pada Gambar 2 .

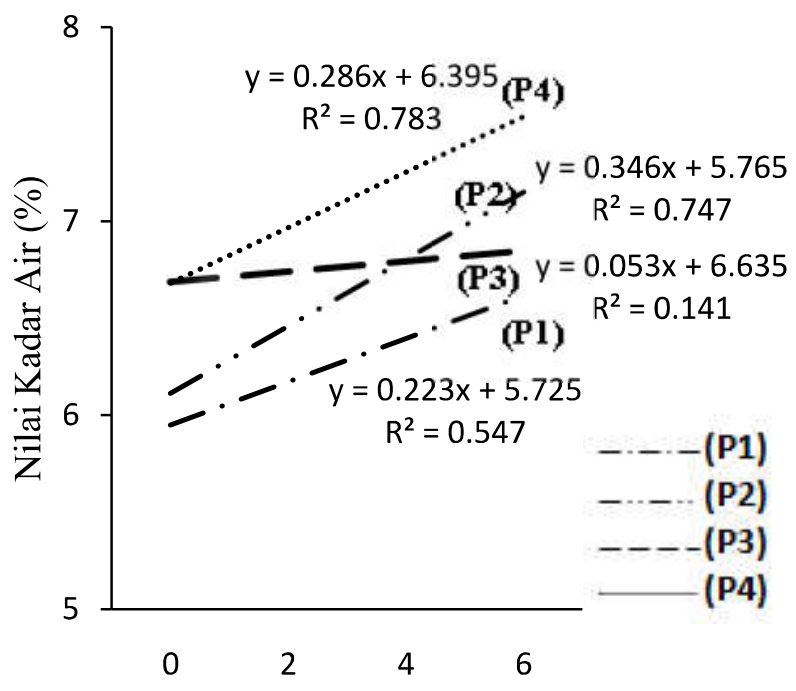

Perlakuan Konsentrasi Perekat (\%)

Gambar 2. Hubungan Interaksi Antara Komposisi Bahan dengan Konsentrasi Perekat Terhadap Nilai Kadar Air

Gambar 2 dapat dilihat komposisi bahan cangkang dan tankos 1:10 (P1), 1:15 (P2),1:20 (P3), dan 1:25 (P4) menunjukan adanya kecenderungan semakin banyak konsentrasi perekat yang ditambahkan pada pembuatan briket bioarang, maka kadar air akan semakin meningkat. Hal ini disebabkan adanya penambahan kadar air dari bahan perekat itu sendiri sehingga kadar air briket bioarang akan meningkat pula. Riseanggara (2008); Ismayana (2010) mengatakan, penambahan jumlah perekat secara umum dapat meningkatkan nilai kalor briket, karena adanya penambahan unsur karbon yang ada pada perekat. Selain itu, rendahnya kadar air akan memudahkan briket dalam penyalaannya, tidak banyak menimbulkan asap pada pembakaran. Penelitian dilakukan Gandhi (2010) menyatakan, adanya penambahan perekat yang banyak otomatis meningkatkan nilai kadar air yang banyak sebagai media pelarut tepungnya. Perlakuan kadar perekat memberikan pengaruh yang nyata terhadap kadar air briket, sehingga dengan kadar perekat yang semakin tinggi maka kadar air briket yang dihasilkan semakin tinggi juga. Hubungan ini dapat disebabkan karena air yang terkandung dalam perekat akan masuk dan terikat dalam pori arang (Saktiawan, 2000). Penambahan airdari setiap persentase perekat yang semakin meningkat menyebabkan jumlah air yang dapat diikat dalam pori arang semakin banyak sehingga memberikan penambahan terhadap kadar air briket arang. Menurut Pari et al. (1990); Saktiawan (2000) yang menyatakan bahwa semakin tinggi kadar perekat maka kadar air yang dihasilkan semakin besar, dimana menurut Wiyandi (1975); Saktiawan (2000) perekat tapioka memiliki sifat kelembaban yang tinggi sehingga kadar airnya akan lebih tinggi. Selain itu juga masih terdapatnya kadar air yang tinggi disebabkan salah satu sifat dari briket arang yaitu bersifat higroskopis sehingga pada saat pembuatan briket masih ada air dari luar yang terikat, arang memiliki kemampuan menyerap air yang besar dari udara sekelilingnya yang dipengaruhi oleh luas permukaan dan pori-pori arang (Earl,1974; Saktiawan, 2000).

Tingginya kadar air pada perlakuan perbandingan komposisi bahan cangkang dan tankos kelapa sawit, dimana tankos memiliki komposisi lebih banyak dari cangkang, sehingga diduga pada tankos sawit memiliki ukuran partikel yang lebih besar dan jumlah pori-pori yang lebih banyak, selain itu juga tandan kosong kelapa 
sawit masih dimungkinkan mengandung komponen-komponen kimia seperti selulosa, lignin dan hemiselulosa. Briket yang memiliki berat jenis yang rendah berarti memiliki pori-pori (rongga- rongga) sel yang besar. Menurut Sudrajat (1984); Saktiawan (2000) menyatakan bahwa briket yang berasal dari bahan baku yang berkerapatan rendah memiliki kadar air yang lebih tinggi daripada briket dengan bahan baku yang berkerapatan tinggi.

Menurut Wijayanti (2009) kadar air yang tinggi diduga jumlah pori-pori masih cukup banyak dan mampu menyerap air, sesuai dengan penelitian Triono (2006) dimana jumlah pori-pori yang lebih banyak dan adanya kandungan komponenkomponen kimia, seperti selulosa, lignin, dan hemiselulosa juga dapat mempengaruhi adanya kandungan nilai kadar air yang tinggi pada briket. Nilai kadar air yang tinggi diduga memiliki jumlah partikel yang berukuran kecil lebih banyak dibandingkan dengan yang lainnya sehingga air yang terkandung di dalam briket lebih tinggi ini terkait dengan sifat higrokopis briket, yaitu daya menyerap air dari udara sekelilingnya. Menurut Budi (2003); Sani (2009) dimana briket yang mempunyai ukuran partikel lignoselulosa yang semakin kecil dan banyak jumlahnya mempunyai kadar air yang tinggi. Partikel yang lebih kecil sangat dipengaruhi oleh luas permukaan pori-pori arang yang terbentuk besar dan jumlah karbon terikat arang yang tinggi. Dengan demikian semakin besar kadar karbon terikat pada briket, kemampuan menyerap air semakin besar (Earl, 1974; Sani, 2009). Menurut Triono (2006) selain dipengaruhi oleh ukuran partikel dan jumlah pori-pori, tinggi rendahnya kadar air diduga juga dipengaruhi oleh kadar abu dimana semakin tinggi kadar abu maka akan semakin rendah kadar air. Nilai rata-rata kadar air briket bioarang pada berbagai perlakuan disajikan pada Gambar 3.

Gambar 3 nilai rata-rata kadar air briket bioarang berbagai perlakuan menunjukan dari perlakuan tersebut, perlakuan K2P4 memiliki nilai kadar air yang paling tinggi dengan nilai $7,46 \%$, sedangkan untuk perlakuan K0P1 memiliki nilai kadar air yang paling rendah dengan nilai $5,70 \%$. Dengan demikian, nilai ratarata kadar air antara 5,70\% sampai dengan $7,46 \%$ masih memenuhi standar syarat mutu yang ditetapkan oleh SNI (8\%), dan juga masih memenuhi standar mutu buatan Jepang (6-8 \%), Inggris (3,6 \%) maupun standar yang ditetapkan oleh Amerika (6,2 $\%)$.

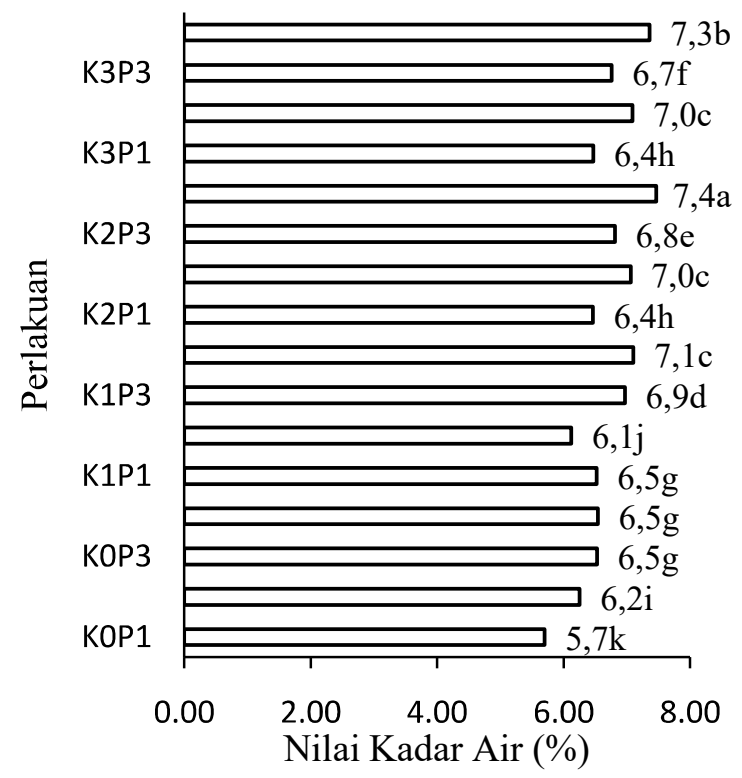

Keterangan :

$\mathrm{K} 0=$ perekat $0 \% \quad \mathrm{P} 1=$ cangkang:tankos 1:10

$\mathrm{K} 1=$ perekat $2 \% \quad \mathrm{P} 2=$ cangkang:tankos 1:15

$\mathrm{K} 2=$ perekat $4 \% \quad \mathrm{P} 3=$ cangkang:tankos 1:20

$\mathrm{K} 3=$ perekat $6 \% \quad \mathrm{P} 4=$ cangkang:tankos 1:25

Gambar 3. Nilai Rata-Rata Kadar Air Briket Bioarang pada Berbagai Perlakuan

\section{B. Kadar Abu}

Abu merupakan bagian yang tersisa dari hasil pembakaran, menurut Santosa et al. (2010) dalam hal ini abu yang dimaksud adalah abu sisa pembakaran briket, yang salah satu penyusunya adalah silika dan pengaruhnya kurang baik terhadap nilai kalor briket arang yang dihasilkan.

Hasil uji lanjut DMRT pada taraf 5 persen menunjukan bahwa interaksi antara komposisi bahan dengan konsentrasi perekat memberikan pengaruh sangat nyata terhadap nilai kadar abu. Hubungan interaksi antara komposisi bahan dengan konsentrasi perekat terhadap nilai kadar abu briket bioarang disajikan pada Gambar 4.

Gambar 4 dapat dilihat komposisi bahan cangkang dan tankos sawit 1:20 (P3) dan 1:25 (P4) menunjukan semakin banyak 
konsentrasi perekat, maka nilai kadar abu akan semakin naik. Hal ini diduga karena adanya penambahan kadar abu dari perekat yang ditambahkan. Menurut Saktiawan (2000) dengan semakin tingginya kadar perekat maka kadar abu briket menjadi semakin tinggi. Hal ini disebabkan karena adanya penambahan kadar abu dari perekatyang digunakan. Terdapat suatu fenomena yang menarik pada perbandingan komposisi bahan cangkang dan tankos sawit $1: 15$ (P2), dimana pada perbandingan komposisi bahan tersebut semakin banyak konsentrasi perekat kanji, maka nilai kadar abu akan semakin menurun. Hal ini diduga karena penambahan perbandingan komposisi bahan tersebut mempengaruhi kadar abu pada campuran briket bioarang tankos. Menurut Ismayana (2010) menunjukan bahwa semakin banyak penambahan bahan perekat, maka kadar abu akan mengalami penurunan.

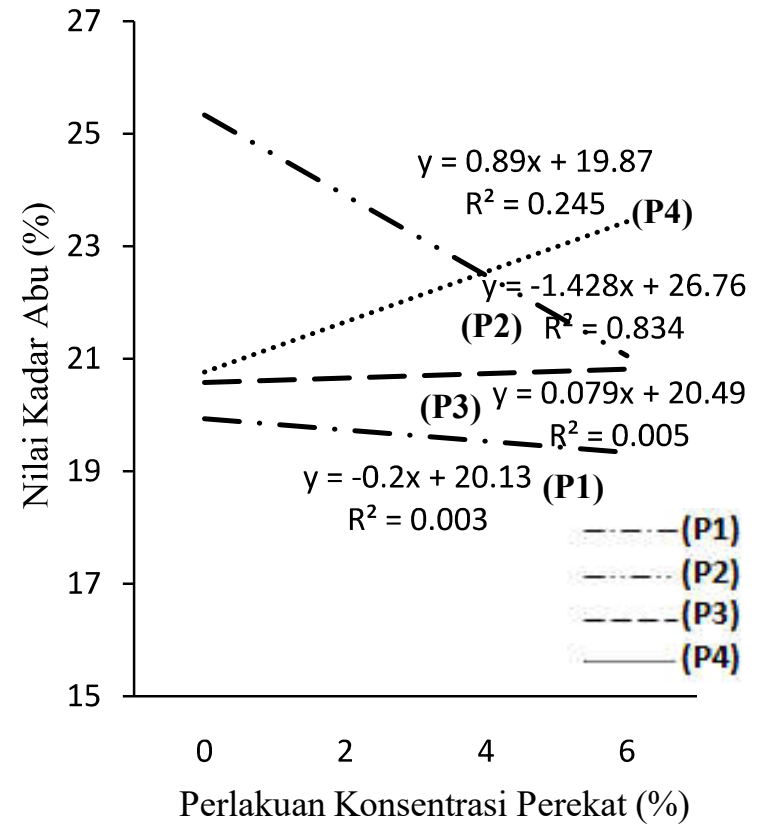

Gambar 4. Hubungan Interaksi Antara Komposisi Bahan dengan Konsentrasi Perekat Terhadap Nilai Kadar Abu

Kenaikan kadar abu pada masingmasing perlakuan diduga karena adanya kandungan silika. Menurut Hendra dan Darmawan (2000); Triono (2006) menyatakan bahwa penambahan persentase arang tempurung kelapa dapat menyebabkan nilai kadar abu briket akan meningkat, sesuai dengan penelitian Saktiawan (2000) dimana menyebutkan bahwa faktor lain yang mempengaruhi tingginya kadar abu briket dimungkinkan karena adanya kandungan silika yang cukup tinggi pada bahan. Menurut Sani (2009) nilai kadar abu yang tinggi pada briket diduga mempunyai kadar garam-garam karbon dari kalium, kalsium, magnesium dan kadar silika yang terkandung tinggi. Kadar silika mempunyai dampak yang negatif terhadap nilai kalor, yaitu kadar silika yang tinggi menurunkan nilai kalor. Penelitian dilakukan Hendra dan Darmawan (2000); Wijayanti (2009) adanya kandungan nilai kadar abu yang tinggi juga diduga adanya kandungan silika dalam bahan. Nilai rata-rata kadar abu briket bioarang pada berbagai perlakuan disajikan pada Gambar 5.

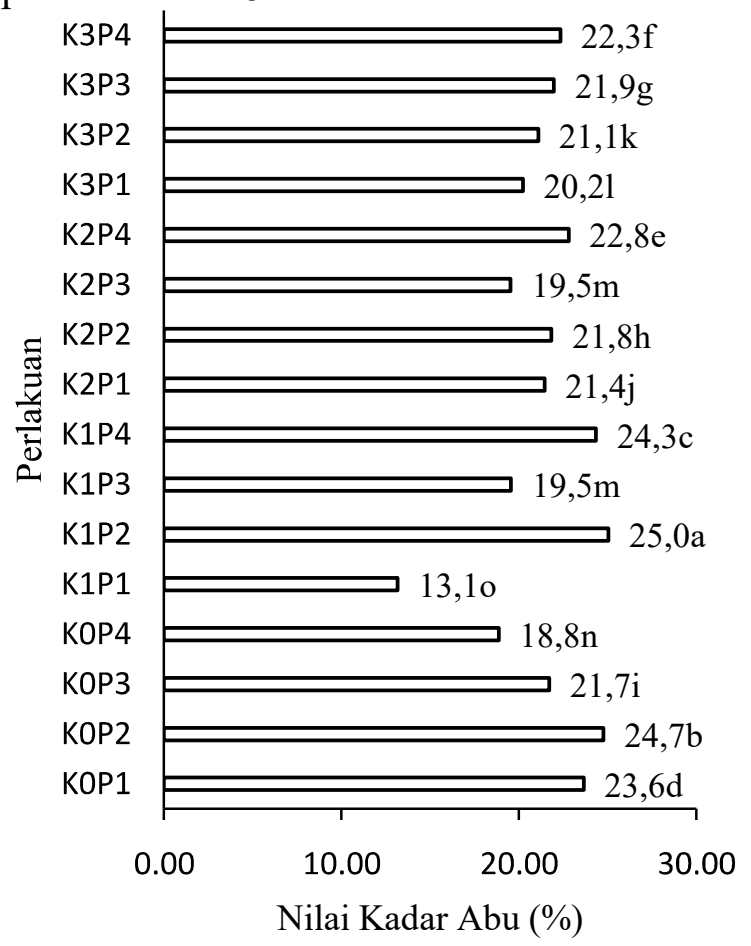

Keterangan :

$\mathrm{K} 0=$ perekat $0 \% \quad \mathrm{P} 1=$ cangkang:tankos $1: 10$ $\mathrm{K} 1=$ perekat $2 \% \quad \mathrm{P} 2=$ cangkang:tankos $1: 15$ $\mathrm{K} 2=$ perekat $4 \% \quad \mathrm{P} 3=$ cangkang:tankos 1:20 $\mathrm{K} 3=$ perekat $6 \% \quad \mathrm{P} 4=$ cangkang:tankos $1: 25$

Gambar 5. Nilai Rata-Rata Kadar Abu Briket Bioarang pada Berbagai Perlakuan

Gambar 5 nilai rata-rata kadar abu briket bioarang pada berbagai perlakuan menunjukan bahwa dari perlakuan tersebut, perlakuan K1P2 memiliki nilai kadar abu yang paling tinggi dengan nilai 25,05 \%, sedangkan untuk perlakuan K1P1 memiliki nilai kadar abu yang paling rendah dengan 
nilai $13,17 \%$. Dengan demikian, nilai ratarata kadar abu antara $13,17 \%$ sampai dengan 25,05 \% tidak dapat memenuhi standar syarat mutu yang ditetapkan oleh SNI (8 \%), dan juga belum dapat memenuhi standar mutu buatan Jepang (3-6\%), Inggris $(5,9 \%)$ maupun standar yang ditetapkan oleh Amerika (8,3\%).

\section{Kadar Zat Menguap}

Menurut Trisasiwi et al. (2012) volatile matter merupakan material yang mudahmenguap dalamarang yang biasanya terdiri dari metana, senyawa hidrokarbon, hidrogen, dan gas yang tidak mudah terbakar seperti karbondioksida dan nitrogen. Menurut Rusliana dan Saleh (2010) tujuan penentuan kadar zat menguap ini adalah untuk mengetahui kandungan senyawa yang mudah menguap yang terkandung di dalam briket.

Hasil uji lanjut DMRT pada taraf 5 persen menunjukan bahwa interaksi antara komposisi bahan dengan konsentrasi perekat memberikan pengaruh sangat nyata terhadap nilai kadar zat menguap. Hubungan interaksi antara komposisi bahan dengan konsentrasi perekat terhadap nilai kadar zat menguap briket bioarang disajikan pada Gambar 6 .

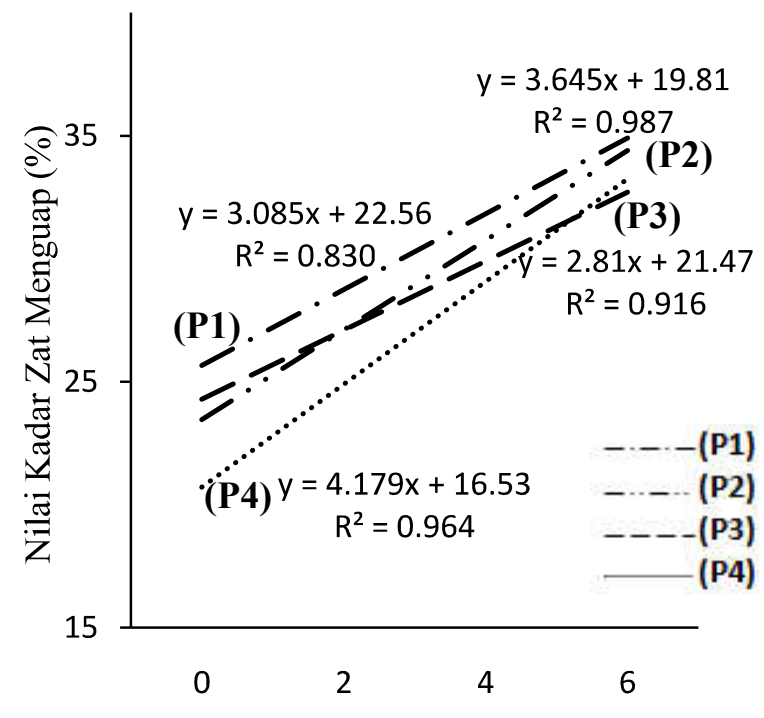

Perlakuan Konsentrasi Perekat (\%)

Gambar 6. Hubungan Interaksi Antara Komposisi Bahan dengan Konsentrasi Perekat Terhadap Nilai Kadar Zat Menguap
Gambar 6 dapat dilihat komposisi bahan cangkang dan tankos sawit 1:10 (P1), 1:15 (P2), 1:20 (P3) dan 1:25 (P4) menunjukkan semakin banyak konsentrasi perekat kanji, maka nilai kadar zat menguap akan semakin naik. Hal ini diduga karena adanya kandungan zat menguap yang ada di dalam perekat kanji. Menurut Saktiawan (2000) menunjukkan bahwa kadar perekat yang semakin tinggi akan menyebabkan kadar zat menguap briket semakin bertambah. Hal ini disebabkan karena adanya kandungan zat-zat menguap yang terdapat pada perekat yang digunakan ikut menguap. Kandungan zat menguap tersebut akan menyebabkan banyak asap sewaktu dilakukan pembakaran pada briket. Pada waktu pemanasan briket, perekat yang digunakan ikut menguap sehingga kadar zat menguap briket yang dihasilkan menjadi besar, sesuai hasil penelitian Pari et al. (1990); Saktiawan (2000) menyatakan bahwa ada kecenderungan makin besar perekat yang digunakan maka kadar zat menguap semakin bertambah.

Menurut Wijayanti (2009) perekat tapioka dalam penggunaan pembuatan briket menimbulkan asap yang relatif sedikit dibandingkan dengan bahan perekat lainnya. Selain itu, perekat pati dalam bentuk cair sebagai bahan perekat menghasilkan briket dengan kadar zat menguap yang bernilai rendah (Sudradjat, 2006; Ismayana, 2010). Menurut Raharjo (2006); Sani (2009) nilai kadar zat menguap briket yang tinggi diduga mempunyai nilai fuel ratio rendah yang menyebabkan jumlah karbon dalam briket banyak yang terbakar. Kadar zat menguap yang tinggi memudahkan penyalaan. Dengan nilai fuel ratio yang rendah jumlah karbon yang terbakar akan semakin banyak. Tinggi rendahnya kadar zat menguap pada briket diduga disebabkan oleh kesempurnaan proses karbonisasi dan juga dipengaruhi oleh waktu maupun suhu proses pengarangan, dimana semakin besar suhu dan waktu pengarangan maka semakin banyak zat menguap yang terbang, sehingga pada saat pengujian zat menguap akan diperoleh zat menguap rendah (Triono, 2006). Nilai ratarata kadar zat menguap briket bioarang pada 
berbagai perlakuan disajikan pada Gambar 7.

Gambar 7 nilai rata-rata kadar zat menguap briket bioarang pada berbagai perlakuan menunjukan bahwa dari perlakuan tersebut, perlakuan K3P4 memiliki nilai kadar zat menguap/terbang yang paling tinggi dengan nilai 34,24\%, sedangkan untuk perlakuan K0P4 memiliki nilai kadar zat menguap yang paling rendah dengan nilai $21,42 \%$. Dengan demikian, nilai ratarata kadar zat menguap antara 21,42 \% sampai dengan 34,24 \% masih belum memenuhi standar syarat mutu yang ditetapkan oleh SNI (15\%) maupun standar syarat mutuInggris $(16,4 \%)$, tetapi sebagian perlakuan memenuhi standar syarat mutu buatan Jepang (15-30 \%) dan standar yang ditetapkan oleh Amerika (19-28 \%).

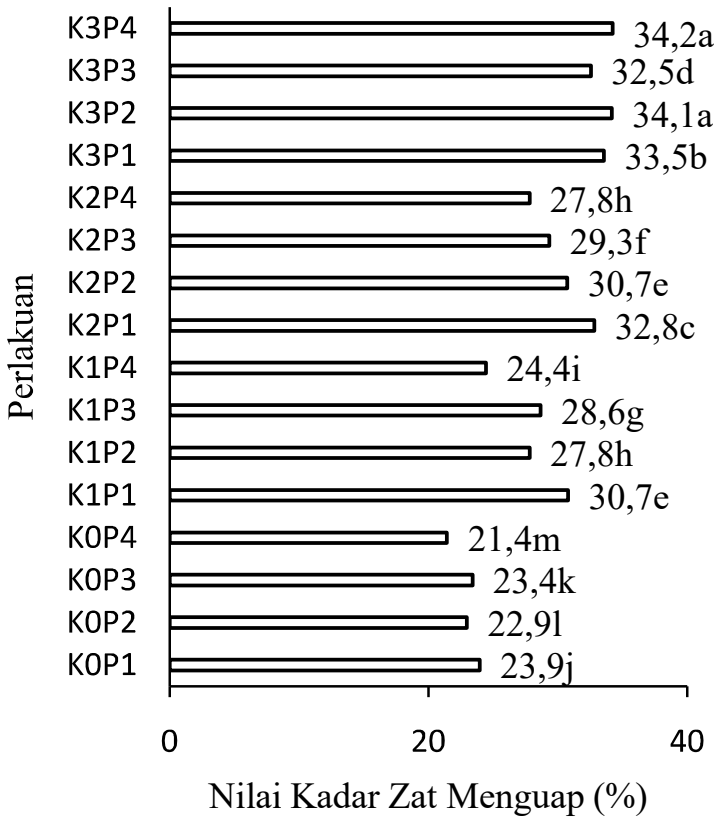

Keterangan :

$\mathrm{K} 0=$ perekat $0 \% \quad \mathrm{P} 1=$ cangkang:tankos $1: 10$

$\mathrm{K} 1=$ perekat $2 \% \quad \mathrm{P} 2=$ cangkang:tankos $1: 15$

$\mathrm{K} 2=$ perekat $4 \% \quad \mathrm{P} 3=$ cangkang:tankos 1:20

$\mathrm{K} 3=$ perekat $6 \% \quad \mathrm{P} 4=$ cangkang:tankos 1:25

Gambar 7. Nilai Rata-Rata Kadar Zat Menguap Briket Bioarang pada Berbagai Perlakuan

\section{Kadar Karbon Terikat}

Kadar karbon terikat merupakan fraksi karbon yang terikat di dalam arang selain fraksi air, zat mudah menguap dan abu (Abidin, 1973; Triono, 2006). Keberadaan karbon terikat di dalam briket arang dipengaruhi oleh nilai kadar abu dan kadar zat menguap/terbang.

Hasil uji lanjut DMRTpada taraf 5 persen menunjukan bahwa interaksi antara komposisi bahan dengan konsentrasi perekat memberikan pengaruh sangat nyata terhadap nilai kadar karbon terikat. Hubungan interaksi antara komposisi bahan dengan konsentrasi perekat terhadap nilai kadar karbon terikat briket bioarang disajikan pada Gambar 8 .

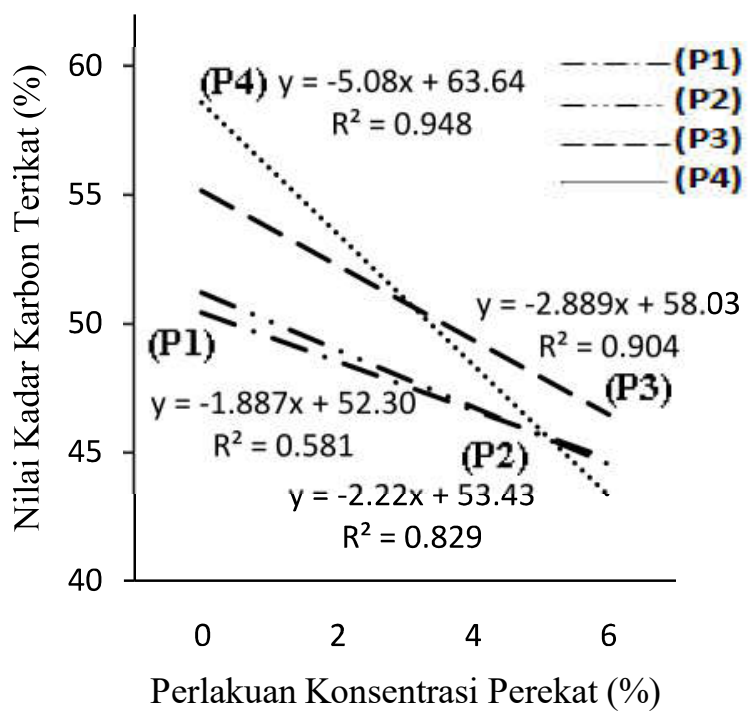

Gambar 8. Hubungan Interaksi Antara Komposisi Bahan dengan Konsentrasi Perekat terhadap Nilai Kadar Karbon Terikat

Gambar 8 dapat dilihat komposisi bahan cangkang dan tankos sawit 1:10 (P1), 1:15 (P2), 1:20 (P3) dan 1:25 (P4) menunjukan semakin banyak konsentrasi perekat yang digunakan, maka nilai kadar karbon terikat akan semakin menurun. Hal ini diduga karena kandungan lignin dalam $\mathrm{P}$ băhan

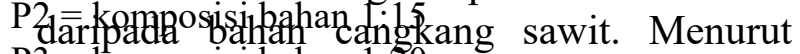

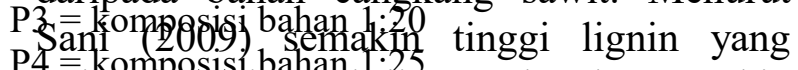
P $4=$ komposisi bahan 1 :ij 5 et, maka akansemakin besar nilai kadar karbon terikatnya. Selain itu juga, nilai karbon terikat dipengaruhi besar kecilnya nilai kadar air, kadar abu dan kadar zat menguap, pada briket hasilnya diharapkan memiliki kadar karbon terikat tinggi. Menurut Saktiawan (2000) dikarenakan briket mempergunakan bahan dengan kadar perekat tinggi memiliki kadar zat mudah menguap dan kadar abu yang lebih tinggi dibandingkan dengan briket 
yang menggunakan kadar perekat yang rendah. Dimana kadar karbon terikat diperoleh dari pengurangan berat keseluruhan briket oleh kadar zat mudah menguap dan kadar abu (100\% - kadar abu + kadar zat mudah menguap), jika kadar abu dan kadar zat mudah menguap tinggi, maka akan dihasilkan kadar karbon terikat yang rendah ataupun sebaliknya.

Menurut Wijayanti (2009) adanya kadar zat menguap yang menurun mampu menaikan nilai kadar karbon terikat briket, selain itu nilai kadar air yang rendah mempengaruhi nilai kadar karbon terikat briket, sehingga mengalami peningkatan juga. Menurut Abidin (1973); Wijayanti (2009) keberadaan kadar karbon terikat di dalam briket akan dipengaruhi oleh nilai kadar abu dan kadar zat menguap. Nilai ratarata kadar karbon terikat briket bioarang pada berbagai perlakuan disajikan pada Gambar 9.

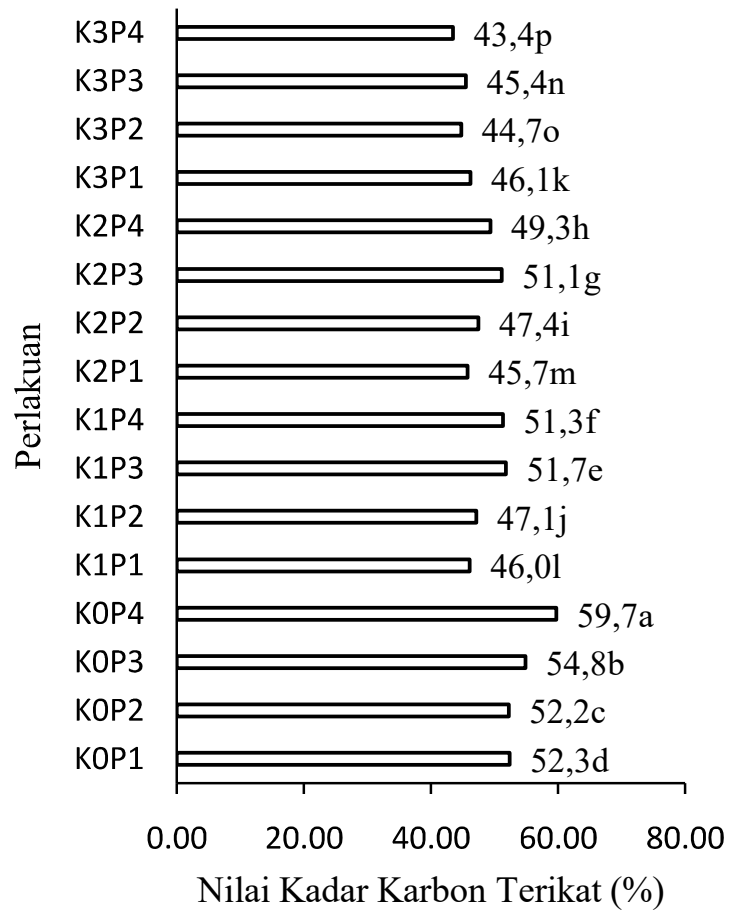

Keterangan :

$\mathrm{K} 0=$ perekat $0 \% \quad \mathrm{P} 1=$ cangkang:tankos $1: 10$

$\mathrm{K} 1=$ perekat $2 \% \quad \mathrm{P} 2=$ cangkang:tankos $1: 15$

$\mathrm{K} 2=$ perekat $4 \% \quad \mathrm{P} 3=$ cangkang:tankos 1:20

$\mathrm{K} 3=$ perekat $6 \% \quad \mathrm{P} 4=$ cangkang:tankos 1:25

Gambar 9. Nilai Rata-Rata Kadar Karbon Terikat Briket Bioarang pada Berbagai Perlakuan
Gambar 9 nilai rata-rata kadar karbon terikat briket bioarang pada berbagai perlakuan menunjukan bahwa dari perlakuan tersebut, perlakuan K0P4 memiliki nilai kadar karbon terikat yang paling tinggi dengan nilai 59,71 \%, sedangkan untuk perlakuan K3P4 memiliki nilai kadar karbon terikat yang paling rendah dengan nilai 43,42 $\%$. Dengan demikian, nilai rata-rata kadar karbon terikat antara 43,42\% sampai dengan $59,71 \%$ masih belum memenuhi standar syarat mutu yang ditetapkan oleh SNI (70 $\%)$ maupun standar syarat mutuInggris $(75,3$ $\%$ ), sebagian perlakuan memenuhi standar syarat mutu buatan Jepang (60-80 \%) ataupun standar yang ditetapkan oleh Amerika (60\%).

\section{E. Kerapatan}

Kerapatan merupakan perbandingan antara berat dan volume briket bioarang tankos. Besar kecilnya kerapatan dipengaruhi oleh ukuran dan kehomogenan penyusun briket tersebut. Tinggi rendahnya kerapatan briket bioarang tankos sangat berpengaruh terhadap kualitas briket bioarang tankos, terutama nilai kalor yang dihasilkan.

Hasil uji lanjut DMRTpada taraf 5 persen menunjukan bahwa interaksi antara komposisi bahan dengan konsentrasi perekat memberikan pengaruh sangat nyata terhadap nilai kerapatan. Hubungan interaksi antara komposisi bahan dengan konsentrasi perekat terhadap nilai kerapatan briket bioarang disajikan pada Gambar 10.

Gambar 10 dapat dilihat komposisi bahan cangkang dan tankos sawit sawit 1:10 (P1), 1:15 (P2), 1:20 (P3) dan 1:25 (P4) menunjukan semakin banyak konsentrasi perekat yang digunakan, maka nilai kerapatan akan semakin naik. Hal ini diduga karena perekat mampu mengikat partikelpartikel arang dan memiliki daya rekat yang baik. Menurut Hendra et al. (1990); Saktiawan (2000) mengatakan bahwa meningkatnya kadar perekat yang diberikan pada pembuatanbriket akan mempengaruhi kerapatannya yang semakin besar. Hal ini disebabkan adanya penambahan daya perekat dalam ikatan briket tersebut. 


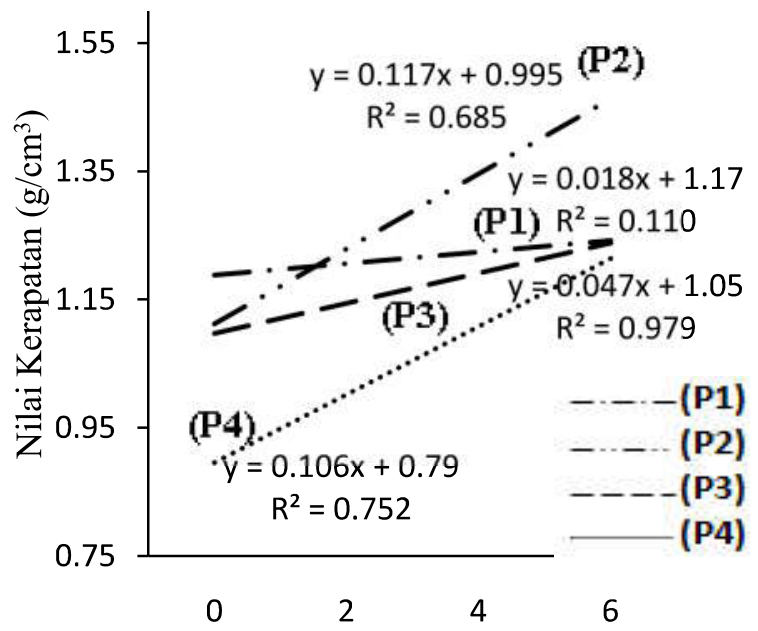

Perlakuan Konsentrasi Perekat (\%)

Gambar 10. Hubungan Interaksi Antara Komposisi Bahan dengan Konsentrasi Perekat Terhadap Nilai Kerapatan

Semakin seragam atau homogen ukuran arang dalam briket menghasilkan kepadatan dan kerapatan yang tinggi. Nilai kerapatan yang tinggi menghasilkan kualitas briket yang lebih baik. Menurut Nurhayati (1983); Sani (2009) nilai kerapatan yang tinggi diduga arang yang dihasilkan lebih homogen atau lebih seragam dan kepadatannya lebih tinggi. Ukuran partikel yang lebih kecil dapat memperluas bidang ikatan antara serbuk, sehingga dapat meningkatkan kerapatan briket (Masturin, 2002; Santoso et al. 2010), sesuai penelitian Masturin (2002); Wijayanti (2009) menyatakan bahwa ukuran arang yang cenderung lebih halus dan seragam mengakibatkan ikatan antar arang lebih maksimal. Hal ini menyebabkan ikatan antar serbuk menjadi lebih kokoh dan kuat dan dapat meningkatkan nilai kerapatan briket. Nilai rata-rata kerapatan briket bioarang pada berbagai perlakuan disajikan pada Gambar 11.

Gambar 11 nilai rata-rata kerapatan briket bioarang pada berbagai perlakuan menunjukan bahwa dari perlakuan tersebut, perlakuan K3P2 memiliki nilai kerapatan yang paling tinggi dengan nilai $1,51 \mathrm{~g} / \mathrm{cm}^{3}$, sedangkan untuk perlakuan K0P4 memiliki nilai kerapatan yang paling rendah dengan nilai $0,84 \mathrm{~g} / \mathrm{cm}^{3}$. Dengan demikian,nilai ratarata kerapatan antara $0,84 \mathrm{~g} / \mathrm{cm}^{3}$ sampai dengan $1,51 \mathrm{~g} / \mathrm{cm}^{3}$ masih dapat memenuhi standar syarat mutu yang ditetapkan oleh standar mutu Jepang $\left(1,0-1,2 \mathrm{~g} / \mathrm{cm}^{3}\right)$ tetapi hanya sebagian perlakuan memenuhi standar syarat mutu buatan Amerika $\left(1 \mathrm{~g} / \mathrm{cm}^{3}\right)$, sedangkan semua perlakuan belum memenuhi standar syarat mutu yang ditetapkan oleh Inggis $\left(0,46 \mathrm{~g} / \mathrm{cm}^{3}\right)$ maupun standar SNI $\left(0,44 \mathrm{~g} / \mathrm{cm}^{3}\right)$.

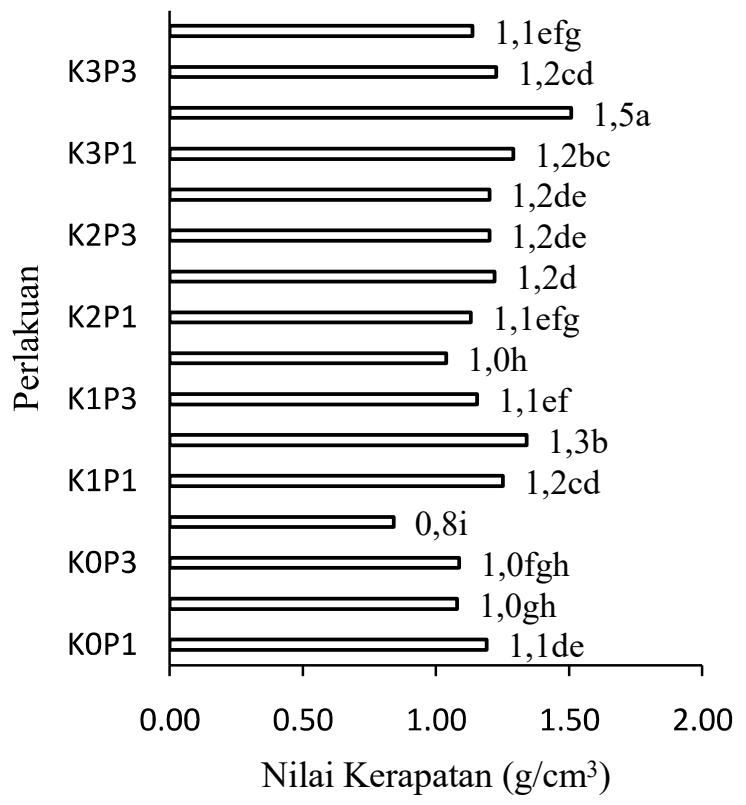

Keterangan :

$\mathrm{K} 0=$ perekat $0 \% \quad \mathrm{P} 1=$ cangkang:tankos $1: 10$

$\mathrm{K} 1=$ perekat $2 \% \quad \mathrm{P} 2=$ cangkang:tankos 1:15

$\mathrm{K} 2=$ perekat $4 \% \quad \mathrm{P} 3=$ cangkang:tankos 1:20

$\mathrm{K} 3=$ perekat $6 \% \quad \mathrm{P} 4=$ cangkang:tankos 1:25

Gambar 11. Nilai Rata-Rata Kerapatan Briket Bioarang pada Berbagai

Perlakuan

\section{F. Keteguhan Tekan}

Keteguhan tekan briket merupakan kemampuan briket untuk memberikan daya tahan atau kekompakan briket terhadap pecah atau hancurnya briket jika diberikan beban pada benda tersebut (Triono, 2006).

Hasil uji lanjut DMRT pada taraf 5 persen menunjukan bahwa interaksi antara komposisi bahan dengan konsentrasi perekat memberikan pengaruh sangat nyata terhadap nilai keteguhan tekan. Hubungan interaksi antara komposisi bahan dengan konsentrasi perekat terhadap nilai keteguhan tekan briket bioarang disajikan pada Gambar 12.

Gambar 12 dapat dilihat komposisi bahan cangkang dan tankos 1:10 (P1), 1:15 (P2), 1:20 (P3) dan 1:25 (P4) semakin banyak konsentrasi perekat digunakan, nilai 
keteguhan tekan akan semakin naik. Hal ini diduga karena semakin banyak perekat maka homogenitas campuran arang dan perekat makin besar, sehingga daya retaknya semakin besar dan mengakibatkan daya tekannya bertambah. Dalam penelitian yang telah dilakukan oleh Hendra (2010) menunjukan bahwa penambahan perekat sangat mempengaruhi keteguhan tekan produk briket yang dihasilkan. Hal ini sesuai dengan hasil penelitian yang telah dilakukan oleh Sutiyono (2010) menunjukkan bahwa keteguhan tekan briket yang menggunakan perekat kanji lebih besar dibandingkan keteguhan tekan briket yang menggunakan perekat bahan pengikat tetes, hal ini terjadi karena perekat kanji bila dipanaskan dapat membentuk gelatin yang mempunyai daya rekat yang sangat baik. Kecenderungan semakin besar kadar perekat maka keteguhan tekan briket yang dihasilkan semakin tinggi (Saktiawan, 2000), sesuai penelitian Sudrajat (1982); Saktiawan (2000) dengan bertambahnya kadar perekat maka ikatan antar partikel makin kuat, dimana ikatan antar partikel briket yang semakin kuat akan menghasilkan keteguhan tekan briket yang dihasilkan semakin tinggi.

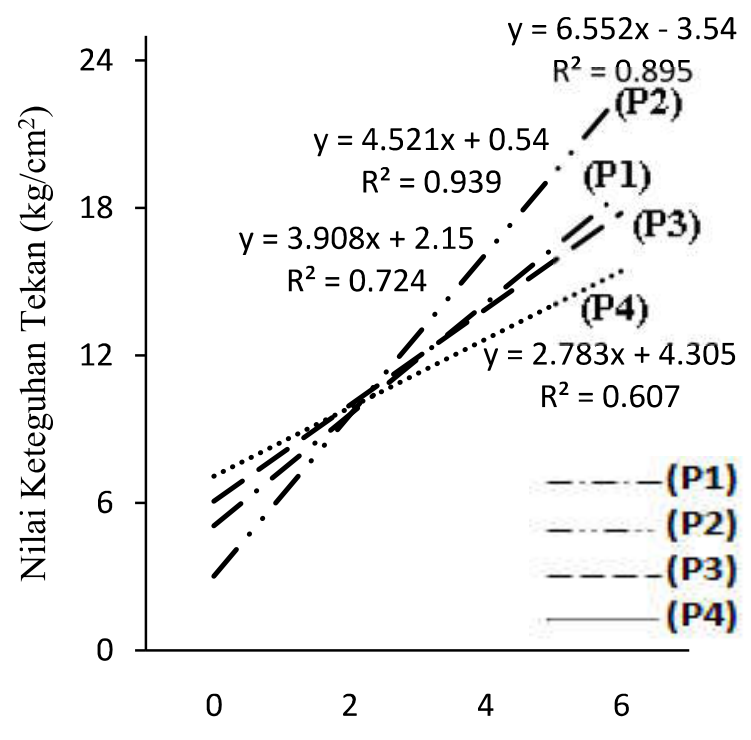

Perlakuan Konsentrasi Perekat (\%)

Gambar 12. Hubungan Interaksi Antara Komposisi Bahan dengan Konsentrasi Perekat Terhadap Nilai Keteguhan Tekan

Meningkatnya nilai keteguhan tekan pada briket bioarang diduga karena ukuran serbuk arang menjadi lebih seragam. Menurut Nurhayati (1983); Triono (2006) menyatakan bahwa permukaan yang seragam akan memudahkan arang untuk menempel dan berikatan satu sama lainnya. Ditambah dengan tekanan pengempaan yang membantu proses pengikatan dan pengisian ruang-ruang yang kosong, Sedangkan ukuran partikel yang tidak seragam akan menyebabkan ikatan antar partikel serbuk arang kurang sempurna, dimana keteguhan tekan meningkat seiring meningkatnya kerapatan.Nilai keteguhan tekan yang tinggi diduga karena memiliki kekompakan dan keseragaman yang tinggi antara partikelbahan baku sehingga menghasilkan kerapatan yang tinggi dan meningkatkan nilai keteguhan tekan. Menurut Nurhayati (1983); Sani (2009) semakin tinggi nilai keseragaman dan kekompakan antara partikel bahan baku, maka semakin tinggi pula keteguhan tekan briket yang dihasilkan, jenis bahan baku sangat mempengaruhi sifat keteguhan tekan briket yang dihasilkan (Hendra, 2010).

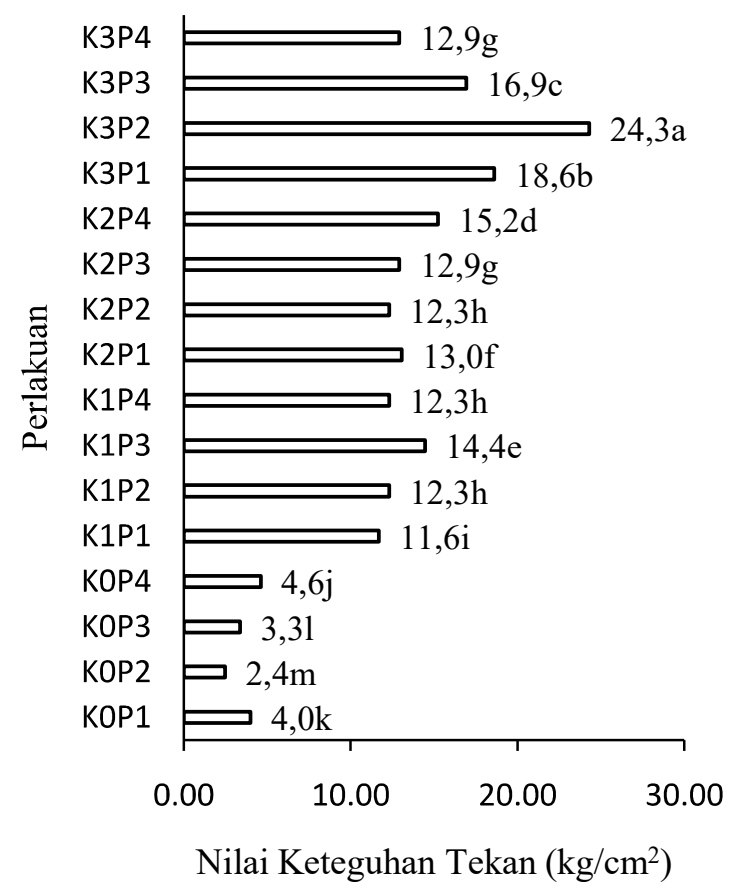

Keterangan :

$\mathrm{K} 0=$ perekat $0 \% \quad \mathrm{P} 1=$ cangkang:tankos $1: 10$

$\mathrm{K} 1=$ perekat $2 \% \quad \mathrm{P} 2=$ cangkang:tankos $1: 15$

$\mathrm{K} 2=$ perekat $4 \% \quad \mathrm{P} 3=$ cangkang:tankos 1:20

$\mathrm{K} 3=$ perekat $6 \% \quad \mathrm{P} 4=$ cangkang:tankos $1: 25$

Gambar 13. Nilai Rata-Rata Keteguhan Tekan Bioarang Pada Berbagai Perlakuan 
Tiap bahan baku memiliki kerapatan berbeda-beda sehingga mengakibatkan nilai keteguhan tekan yang berbeda-beda. Menurut Hendra dan Darmawan (2002); Hendra (2010) semakin kecil ukuran serbuk bahan, maka nilai keteguhan tekannya akan semakin besar. Nilai rata-rata keteguhan tekan briket bioarang pada berbagai perlakuan disajikan pada Gambar 13.

Gambar 13 nilai rata-rata keteguhan tekan briket bioarang pada berbagai perlakuan menunjukkan bahwa dari perlakuan tersebut, perlakuan K3P2 memiliki nilai keteguhan tekan yang paling tinggi dengan nilai $24,30 \mathrm{~kg} / \mathrm{cm}^{2}$, sedangkan untuk perlakuan K0P2 memiliki nilai keteguhan tekan yang paling rendah dengan nilai $2,46 \mathrm{~kg} / \mathrm{cm}^{2}$. Dengan demikian, nilai rata-rata kerapatan antara $2,46 \mathrm{~kg} / \mathrm{cm}^{2}$ sampai dengan $24,30 \mathrm{~kg} / \mathrm{cm}^{2}$ sebagian perlakuan masih dapat memenuhi standar syarat mutu yang ditetapkan oleh standar mutu Inggris $\left(12,7 \mathrm{~kg} / \mathrm{cm}^{2}\right)$ tetapi tidak dapat memenuhi standar syarat mutu buatan Amerika $\left(62 \mathrm{~kg} / \mathrm{cm}^{2}\right)$, Jepang (60-65 $\mathrm{kg} / \mathrm{cm}^{2}$ ).

\section{G. Nilai Kalor Bakar}

Nilai kalor perlu diketahui dalam pembuatan briket bioarang tankos, karena untuk mengetahui nilai panas pembakaran yang dapat dihasilkan oleh briket sebagai bahan bakar, pengujian terhadap nilai kalorbertujuan untuk mengetahui sejauh mana nilai panas pembakaran yang dihasilkan oleh briket bioarang (Triono, 2006)

Hasil uji lanjut DMRT pada taraf 5 persen menunjukkan bahwa interaksi antara komposisi bahan dengan konsentrasi perekat memberikan pengaruh sangat nyata terhadap nilai kalor bakar. Hubungan interaksi antara komposisi bahan dengan konsentrasi perekat terhadap nilai kalor briket bioarang disajikan pada Gambar 14.

Gambar 14 dapat dilihat komposisi bahan cangkang dan tankos sawit 1:10 (P1) dan 1:20 (P3) menunjukkan semakin banyak konsentrasi perekat, maka nilai kalor bakar akan semakin menurun. Hal ini diduga karenaadanya penambahan perekat yang masih memiliki kandungan air cukup tinggi.
Menurut Sutiyono (2010) mengatakan bahwa semakin besar penambahan perekat kanji, maka nilai kalor briket menjadi semakin kecil karena semakin besar perekat yang diberikan menyebabkan semakin besar juga kadar air yang terkandung pada briket karena adanya penambahan air yang berasal dari perekat tersebut. Terdapat suatu fenomena yang cukup menarik pada perbandingan komposisi bahan cangkang dan tankos sawit 1:25 (P4), dimana pada perbandingan komposisi tersebut semakin banyak konsentrasi perekat kanji, maka nilai kalor bakar akan semakin naik. Hal ini diduga karena adanya penambahan bahan perekat kanji. Menurut Ismayana (2010) bahan perekat memiliki sifat dapat meningkatkan nilai kalor, karena mengandung unsur carbon (C).

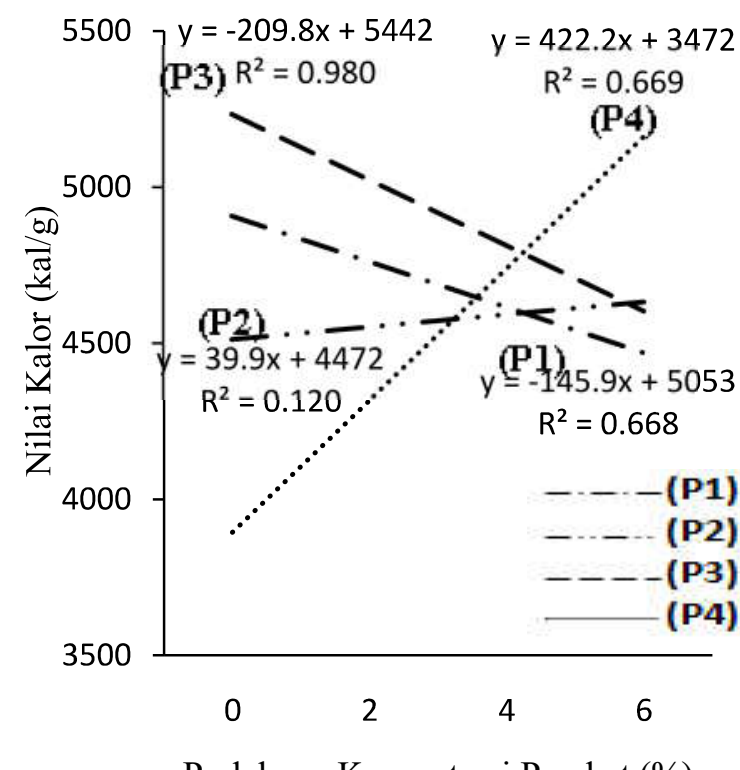

Perlakuan Konsentrasi Perekat (\%)

Gambar 14. Hubungan Interaksi Antara Komposisi Bahan dengan Konsentrasi Perekat terhadap Nilai Kalor

Menurut Obernberger dan Thek (2004); Sani (2009) menyatakan bahwa nilai kalor yang tinggi diduga karena kandungan kadar air yang rendah, kadar zat menguap yang tinggi dan nilai kadar karbon terikat yang tinggi. Semakin tinggi nilai kadar air semakin menurunnya nilai kalor, dikarenakan proses pembakaran kurang efisien, sesuai penelitian Sutiyono (2010) berkurangnya air yang terdapat di dalam briket akan menyebabkan kalor yang dihasilkan dari pembakaran dan 
yang digunakan untuk menguapkan air yangterkandung dalam briket semakin berkurang, sehingga kalor yang dihasilkan briket semakin besar.

Menurut Hendra (2010) faktor jenis bahan baku sangat mempengaruhi besarnya nilai kalor briket yang dihasilkan dan dalam setiap jenis bahan baku briket memiliki nilai kadar zat karbon terikat yang berbeda, sehingga mengakibatkan nilai kalor bakar yang berbeda. Bahan baku yang memiliki nilai kadar karbon terikat yang tinggi akan menghasilkan nilai kalor bakar briket yang tinggi, dimana semakin tinggi nilai kadar karbon terikat akan semakin tinggi nilai kalornya, karena setiap ada reaksi oksidasi akan menghasilkan kalor (Winarni dan Hendra (2003); Hendra (2010).

Tinggi rendahnya nilai kalor bakar dipengaruhi oleh kadar air dan kadar abu briket. Menurut Triono (2006) dalam hasil penelitian sebelumnya mengatakan bahwa semakin rendah nilai kadar air dan kadar abu briket, maka akan meningkatkan nilai kalor bakar briket. Selain itu juga nilai kalor dipengaruhi oleh nilai kadar karbon terikat yang terkandung di dalam briket yang dihasilkan. Semakin tinggi nilai kadar karbon terikat dalam briket, maka semakin tinggi nilai kalor briket.Nilai rata-rata kalor bakar briket bioarang pada berbagai perlakuan disajikan pada Gambar 15.

Gambar 15 nilai rata-rata kalor bakar briket bioarang pada berbagai perlakuan menunjukan bahwa dari perlakuan tersebut, perlakuan K0P3 memiliki nilai kalor yang paling tinggi dengan nilai 5196,00 kal/g, sedangkan untuk perlakuan K0P4 memiliki nilai kalor yang paling rendah dengan nilai $3537,00 \mathrm{kal} / \mathrm{g}$.Dengan demikian, nilai ratarata kalor antara $3537,00 \mathrm{kal} / \mathrm{g}$ sampai dengan 5196,00 kal/g, sebagian perlakuan masih dapat memenuhi standar syarat mutu yang ditetapkan oleh standar mutu SNI $(5000 \mathrm{kal} / \mathrm{g})$ tetapi tidak dapat memenuhi persyaratan mutu Jepang (6000-7000 kal/g) ataupun standar mutu Inggris $(7289 \mathrm{kal} / \mathrm{g}$ ) maupun standar mutu Amerika (6230 kal/g).

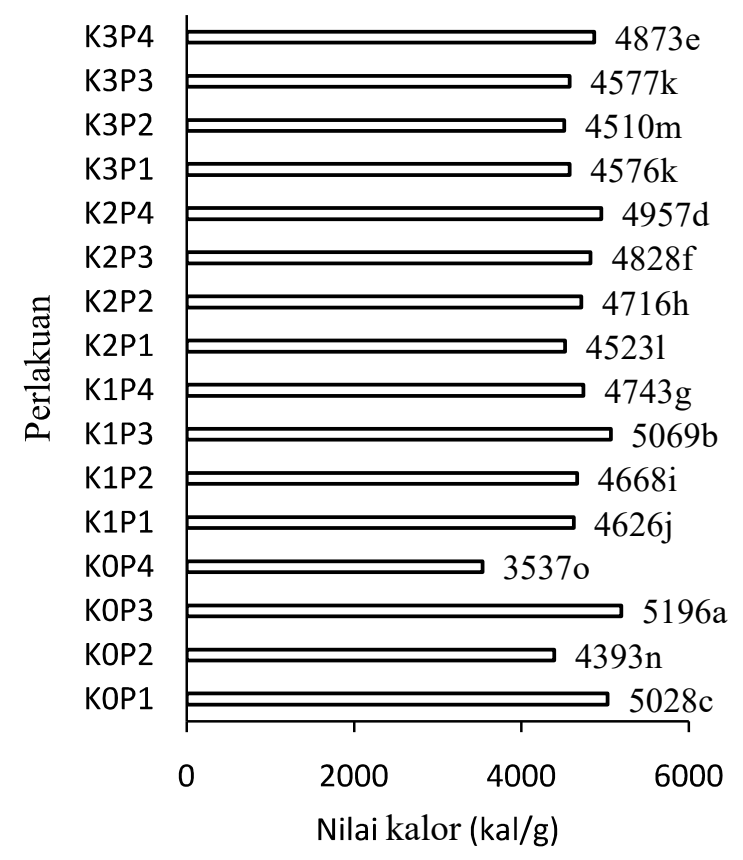

Keterangan :

$\mathrm{K} 0=$ perekat $0 \% \quad \mathrm{P} 1=$ cangkang:tankos 1:10

$\mathrm{K} 1=$ perekat $2 \% \quad \mathrm{P} 2=$ cangkang:tankos 1:15

$\mathrm{K} 2=$ perekat $4 \% \quad \mathrm{P} 3=$ cangkang:tankos 1:20

$\mathrm{K} 3=$ perekat $6 \% \quad \mathrm{P} 4=$ cangkang:tankos 1:25

Gambar 15. Nilai Rata-Rata Nilai Kalor Briket Bioarang Pada Berbagai Perlakuan

\section{KESIMPULAN DAN SARAN}

\section{A. Kesimpulan}

1. Komposisi bahan cangkang dan tandan kosong memberikan pengaruh sangat nyata terhadap variabel pengamatan kadar air, kadar abu, kadar zat menguap, kadar karbon terikat, kerapatan, keteguhan tekan maupun nilai kalor bakar briket

2. Konsentrasi perekat tapioka memberikan pengaruh sangat nyata terhadap variabel pengamatan kadar air, kadar abu, kadar zat menguap, kadar karbon terikat, kerapatan, keteguhan tekan maupun nilai kalor bakar briket.

3. Interaksi antara komposisi bahan dengan konsentrasi perekat memberikan pengaruh sangat nyata terhadap variabel pengamatan kadar air, kadar abu, kadar zat menguap, kadar karbon terikat, kerapatan, keteguhan tekan maupun nilai kalor bakar briket. Perlakuan komposisi cangkang dan tankos 1:20 dengan konsentrasi $2 \%$ perekat tapioka memberikan produk briket bioarang 
tankos yang terbaik dengan nilai kadar air $(6,97 \%)$, nilai kadar abu $(19,54 \%)$, nilai kadar zat menguap $(28,67 \%)$, nilai kadar karbon terikat $(51,78 \%)$, nilai kerapatan $\left(1,14 \mathrm{~g} / \mathrm{cm}^{3}\right)$, nilai keteguhan tekan $(14,45$ $\mathrm{kg} / \mathrm{m}^{2}$ ), dan nilai kalor bakar (5069 kal/g).

\section{B. Saran}

Perlu dilakukan penelitian pembuatan arang tankos dengan waktu pembakaran/pirolisis tepat pada saat pembuatan arang dan dengan suhu yang optimal, sehingga dihasilkan arang sebagai bahan pembuatan briket yang baik, serta perlu adanya rancangan alat pirolisis yang baik untuk pembakaran bahan tandan kosong kelapa sawit, karena tankos merupakan selulosa/serat sifatnya mudah habis terbakar.

\section{DAFTAR PUSTAKA}

Budiman, S., Sukrido dan A. Harliana. 2011. Pembuatan Biobriket Dari Campuran Bungkil Biji Jarak Pagar (Jatropha curcas L.) Dengan Sekam Sebagai Bahan Bakar Alternatif. Jurnal.

Gandhi, A.B. 2010. Pengaruh Variasi Jumlah Campuran Perekat Terhadap Karakter Briket Arang Tongkol Jagung. Jurnal Profesional 8 (1) : -

Hendra, J. 2010. Pemanfaatan Eceng Gondok (Eichornia crassipes L,) Untuk Bahan Baku Briket Sebagai Bahan Bakar Alternatif. JurnalPenelitian Hasil Hutan 29 (2) : 189-210.

Ismayana, A. dan M.R. Afriyanto. 2010. Pengaruh Jenis dan Kadar Bahan Perekat Pada Pembuatan Briket Blotong Sebagai Bahan Bakar Alternatif. Jurnal Teknologi Industri Pertanian 21 (3) : 186-193.

Mulia, A. 2007. Pemanfaatan Tandan Kosong Dan Cangkang Kelapa Sawit Sebagai Briket Arang. Tesis. Sekolah Pasca Sarjana, USU. (Tidak dipublikasikan).

Rusliana, E. dan M. Saleh. 2010. Karakteristik Briket Bioarang Limbah Pisang Dengan Perekat
Tepung Sagu. Seminar Rekayasa Kimia dan Proses. Universitas Khairun Ternate.

Saktiawan, I. 2000. Identifikasi Sifat Fisik dan Kimia Briket Arang Dari Sabut Kelapa (Cocos nucifera L,). Skripsi. Jurusan Teknologi Hasil Hutan, IPB. (Tidak dipublikasikan).

Sani, H.R. 2009. Pembuatan Briket Arang Dari Campuran Kulit Kacang, Cabang dan Ranting Pohon Sengong Serta Sebetan Bambu. Skripsi. Jurusan Teknologi Hasil Hutan, IPB. (Tidak dipublikasikan).

Santosa., Mislaini, R. dan S.P. Anugrah. 2010. Studi Variasi Komposisi Bahan Penyusun Briket Dari Kotoran Sapi dan Limbah Pertanian. Universitas Andalas. Jurnal Teknik Pertanian.

Sutiyono. 2010. Pembuatan Briket Arang Dari Tempurung Kelapa Dengan Bahan Pengikat Tetes Tebu dan Tapioka. Jurnal Kimia dan Teknologi.

Triono, A. 2006. Karakteristik Briket Arang dari Campuran Serbuk Gergajian Kayu Afrika (Maesopsis eminii Engl.) dan Sengon (Paraserianthes falcataria L. Nielsen) dengan Penambahan Tempurung Kelapa (Cocos nuciferaL.). Skripsi. IPB. (Tidak dipublikasikan).

Trisasiwi, W., A. Asnani. dan B. Sumanto. 2012. Perbaikan Tungku Karbonisasi Model Pembakaran Luar (Retort) Untuk Meningkatkan Kinerja Pengarangan. Jurnal. Tektan 4 (1) : $55-65$

Wijayanti, D.S. 2009. Karakteristik Briket Arang dari Serbuk Gergaji dengan Penambahan Arang Cangkang Kelapa Sawit. Jurnal Teknik Pertanian. 